San Jose State University

SJSU ScholarWorks

Master's Theses

Master's Theses and Graduate Research

Summer 2012

\title{
Program Directors' Perceptions of Quality in NATA-Accredited Post-Professional Athletic Training Education Programs
}

Joshua Pendleton

San Jose State University

Follow this and additional works at: https://scholarworks.sjsu.edu/etd_theses

\section{Recommended Citation}

Pendleton, Joshua, "Program Directors' Perceptions of Quality in NATA-Accredited Post-Professional Athletic Training Education Programs" (2012). Master's Theses. 4207.

DOI: https://doi.org/10.31979/etd.fkva-j7c8

https://scholarworks.sjsu.edu/etd_theses/4207

This Thesis is brought to you for free and open access by the Master's Theses and Graduate Research at SJSU ScholarWorks. It has been accepted for inclusion in Master's Theses by an authorized administrator of SJSU ScholarWorks. For more information, please contact scholarworks@sjsu.edu. 


\title{
PROGRAM DIRECTORS' PERCEPTIONS OF QUALITY IN NATA-ACCREDITED POST- PROFESSIONAL ATHLETIC TRAINING EDUCATION PROGRAMS
}

\author{
A Thesis \\ Presented to \\ The Faculty of the Department of Kinesiology \\ San José State University \\ In Partial Fulfillment \\ of the Requirements for the Degree \\ Master of the Arts
}

by

Joshua B. Pendleton

August 2012 
(C) 2012

Joshua B. Pendleton

ALL RIGHTS RESERVED 
The Designated Thesis Committee Approves the Thesis Titled

PROGRAM DIRECTORS' PERCEPTIONS OF QUALITY IN NATA-ACCREDITED POSTPROFESSIONAL ATHLETIC TRAINING EDUCATION PROGRAMS

by

Joshua B. Pendleton

APPROVED FOR THE DEPARTMENT OF KINESIOLOGY

SAN JOSÉ STATE UNIVERSITY

August 2012

Dr. Jay A. Johnson

Department of Kinesiology

Dr. Theodore M. Butryn

Department of Kinesiology

Holly Brown

Department of Kinesiology 


\begin{abstract}
PROGRAM DIRECTORS' PERCEPTIONS OF QUALITY IN NATA-ACCREDITED POSTPROFESSIONAL ATHLETIC TRAINING EDUCATION PROGRAMS
\end{abstract}

\author{
by Joshua B. Pendleton
}

The National Athletic Trainers' Association (NATA) is a member organization that oversees the health care profession of certified athletic trainers. A large body of research focused on the structure and content of curriculum for undergraduate programs has played a prominent role in the increase in their quantity and quality. Although attention has been called to graduate-level athletic-training education programs, there is currently a lack of research focused on NATA-accredited postprofessional athletic training education programs (PPATEPs).

Using qualitative analysis, program directors' perceptions of quality in these NATA-accredited PPATEPs was assessed. In-depth phone interviews were conducted regarding topics such at the accreditation standards, curricular content, perceived benefits of attending a program, and the future or sustainability of accredited PPATEPs. After these topics were discussed with participants, three main themes emerged. Program directors of NATA-accredited PPATEPs undergo a special accreditation process that assesses and attempts to improve upon the quality of their program. Participants felt that there were specific benefits that accreditation serves to highlight. Participants also felt that the future of postprofessional athletic training education was uncertain but on the right track. 


\section{ACKNOWLEDGEMENTS}

There were many people whom without their help this thesis would not have been possible. I'd Like to thank my thesis committee members Holly Brown, Dr. Ted Butryn for their interest, criticism and support. A very special thanks is due to my thesis committee chair, Dr. Jay Johnson, for his inspiration, motivation, and dedication to my thesis. His positivity and enthusiasm drove me when I felt I was beginning to stall.

I'd like to thank my classmates at San José State University and Al Douex for their input during the formation of my thesis topic and contributing to its early shape and form.

I'd like to thank my friends and family for their interest and encouragement. I'd especially like to thank my wife Mary and daughter Talitha for their love, support and understanding during this process. 


\section{TABLE OF CONTENTS}

Page

1. INTRODUCTION 1

The National Athletic Trainers' Association 2

History of Athletic Training Education 3

Evolution of Athletic Training Education Programs 4

Post-Professional Athletic training Education Programs 5

$\begin{array}{ll}\text { Lack of PPATEP Research } & 7\end{array}$

$\begin{array}{ll}\text { Purpose of the Study } & 8\end{array}$

$\begin{array}{ll}\text { Limitations } & 8\end{array}$

$\begin{array}{ll}\text { Delimitations } & 9\end{array}$

Definition of Terms

$\begin{array}{ll}\text { Summary } & 10\end{array}$

2. REVIEW OF LITERATURE 11

$\begin{array}{ll}\text { Nursing } & 11\end{array}$

$\begin{array}{ll}\text { Evidence-Based Medicine } & 12\end{array}$

$\begin{array}{ll}\text { Mentorship } & 13\end{array}$

$\begin{array}{ll}\text { Problems and Challenges } & 14\end{array}$

Research on Post-Professional Athletic Training Education 18

$\begin{array}{ll}\text { Summary } & 21\end{array}$

3. METHODOLOGY 22

$\mathrm{vi}$ 
Qualitative Reasoning $\quad 22$

$\begin{array}{ll}\text { Participants } & 22\end{array}$

$\begin{array}{ll}\text { Instrumentation } & 23\end{array}$

$\begin{array}{ll}\text { Procedures } & 24\end{array}$

Analysis of Data $\quad 24$

$\begin{array}{ll}\text { Summary } & 27\end{array}$

4. RESULTS AND DISCUSSIONS 29

Relationship with Standards and Guidelines $\quad 30$

Benefits of Attending a PPATEP 33

Sustainability of PPATEPs $\quad 40$

$\begin{array}{ll}\text { Summary } & 46\end{array}$

5. CONCLUSIONS 48

Relationship with Standards and Guidelines $\quad 48$

Benefits of Attending a PPATEP $\quad 50$

Sustainability of PPATEPs $\quad 52$

Recommendations for Further Study $\quad 55$

Areas of Future Research 56

Implications $\quad 56$

Summary 58

$\begin{array}{lr}\text { REFERENCES } & 59\end{array}$

APPENDIXES 
A. Interview Guide $\quad 64$

B. Consent Form 66 


\section{Chapter 1}

\section{Introduction}

Research publication and comprehension in athletic training has recently been acknowledged as a necessity to the profession (Martin, 2009). The recent emphasis on research and publication in the field of athletic training suggests that it is vital to the survival and evolution of athletic training (Myer, 2009). Current research in athletic training, predominantly published in the Journal of Athletic Training, has begun to increase in both quantity and quality (Turocy, 2002). Martin et al. (2009) suggest that while research production and comprehension in athletic training is vastly improving, it is "lagging behind" that of other allied health care professions (p. 27).

Research in athletic training education has concentrated on athletic training education program curricula and issues facing both students and program faculty (Neibert, 2009). Although the body of research on athletic training education programs has significantly helped shape undergraduate entry-level athletic training education programs, there is presently a lack of research pertaining to graduatelevel post professional athletic training education programs (PPATEP) (Neibert, 2009). A reflective assessment and analysis could significantly further the advancement and maturation of PPATEPs.

This lack of self-analysis is one of the primary factors responsible for the lack of growth in numbers of PPATEPs in the United States. Although the first undergraduate athletic training undergraduate programs and PPATEPs were 
established only three years apart, the expansion of undergraduate ATEPs has greatly overshadows that of PPATEPs (Delforge, 1999). Although accredited undergraduate programs are currently listed over 360 and rising, PPATEPs are currently at 15 , with one program recently losing accreditation (Commission on Accreditation of Athletic Training Education, 2008; Henry, 2009). The recent loss of an accredited PPATEP highlights a potential crisis in the development and advancement of PPATEPs. It also highlights the growing disparity between the perceived quality of education programs and the regulation of accredited undergraduate ATEPS and accredited PPATEPs (National Athletic Trainers' Association, n.d.). This disparity between the number of undergraduate ATEPs and PPATEPs highlights a difference in challenges faced by program directors and faculty concerning the creation of programs, gaining accreditation, and maintaining accreditation. Although the problems and challenges faced by program directors of undergraduate ATEPs have previously been assessed through research, problems and challenges facing program directors of PPATEPs remain nameless and unexamined.

\section{The National Athletic Trainers' Association}

The National Athletic Trainers' Association (NATA) was established in 1950 by roughly 200 athletic trainers as a means to create a set of professional standards and professional recognition. The NATA currently totals over 30,000 in global membership and has taken many steps to further the profession including 
establishing standards for professionalism, education, certification, research and practice settings (National Athletic Trainers' Association, n.d.).

\section{History of Athletic Training Education}

Education has become the base of development of certified athletic trainers. The first athletic training curriculum was approved by the NATA in 1959 (Delforge, 1999). The Professional Education Committee was formed in 1969 and recognition of the first undergraduate athletic training education programs occurred that same year. These undergraduate programs proliferated throughout the 1970s and in 1986, the NATA Board of Directors called for ATEPs to offer a major field of study in athletic training (Delforge, 1999).

In 1990, the AMA formally recognized athletic training as an allied health care profession. This was a significant landmark in the advancement of the profession of athletic training and athletic training education. Athletic trainers would now be held in the same regard as medical doctors, nurses, chiropractors, physical therapists, and other allied health care professionals. Also, the NATA was now responsible to follow AMA policy regarding accreditation of entry-level programs by the AMA Committee on Allied Health Education and Accreditation (CAHEA) (Delforge, 1999). At the request of the AMA, the CAHEA was later disbanded and an independent agency was formed to oversee the accreditation process called the Commission on Accreditation of Allied Health Education Programs (CAAHEP). The NATA established the Committee on Accreditation of Athletic Training Education (CAATE), which is a member of CAAHEP, to 
independently oversee the accreditation of ATEP's. In June 1998, there were 82 accredited entry-level athletic training education programs. Today that number has risen to over 350 (Commission on Accreditation of Athletic Training Education, 2008). The proliferation of CAATE-accredited education programs has benefitted the profession of athletic training by enhancing and standardizing the education level of all athletic trainers. The establishment of standards of accreditation for education programs has led to an increase in the quality of education received in ATEPs (Turocy, 2002).

\section{Evolution of Athletic Training Education Programs}

While CAATE accreditation of undergraduate ATEPs has increased program quality, research on athletic training education has played the main role in athletic training curriculum and program evolution (Turocy, 2002). A prime example of research's effect on athletic training education is the development of athletic training clinical proficiencies, a major component of undergrad ATEP curriculum. These proficiencies have evolved directly through research conducted and published through the Journal of Athletic Training, which allows ATEP directors to best assess athletic training students' clinical skills (Walker, 2008). Through this example, the focus on both athletic training students and faculty is seen. By asking critical questions about athletic training students, program directors, clinical instructors, and relationships between the three, research has helped shape and reform undergrad ATEPs (Pitney, 2002). Many of the primary research questions 
pertaining to undergrad ATEPs mimic those of other entry-level allied health care professionals, such as nursing education programs (Steves, 2004).

\section{Post-Professional Athletic Training Education Programs}

Graduate, or post-professional, athletic training education programs have been created to further the education of athletic trainers who have completed an entry-level undergraduate program. The first graduate programs emerged in 1972, although there are currently only 15 NATA-accredited PPATEP (Henry, 2009). In 1997, the Post-Professional Educational Council of the NATA Education Council was asked to distinguish the standards and guidelines of post-certification programs (Neibert, 2009). The mission of post-professional education is to expand the depth and breadth of the applied, experimental, and propositional knowledge and skills of the entry-level certified athletic trainer (Commission on Accreditation of Athletic Training Education, 2008).

The educational model for PPATEPs is similar to that of undergraduate ATEPs, consisting of both classroom education and clinical internships (Neibert, 2009). There is, however, much more room for flexibility in the curriculum of PPATEPs. The Standards and Guidelines for Post-Certification Graduate Athletic Training Education Programs identify six principles for continuing education (Commission on Accreditation of Athletic Training Education, 2008). The principles are as follows:

1. Mastery of subject matter. Graduate education facilitates mastery over the content and skills of the discipline at a level appropriate to the 
degree sought.

2. Critical thinking. Graduate education develops and refines critical thinking skills including a thorough knowledge of the assumptions of the discipline and an understanding of viable alternative assumptions.

3. Theoretical understanding. Graduate education provides an understanding of the theoretical bases of the field of study by grounding application and performance in theory.

\section{Proficiency in research and/or creative activities. Graduate} education develops proficiencies that advance the knowledge and activities of the discipline. These proficiencies include good writing skills as well as the ability to present original insights and creative expressions.

5. Service orientation. Graduate education instills responsibility to return the special benefits of graduate study to the larger community.

6. Diverse representation of perspectives. Graduate education provides for intellectually and culturally rich encounters within the discipline. Study and inquiry are conducted in a context sensitive to ethnic and cultural diversity (National Athletic Trainers' Association, 2002, pp. 1-2). Although these principles are present within all NATA-accredited PPATEPs, the emphasis is placed on a variety of educational experiences, leaving much more flexibility in curriculum development by PPATEP directors. This results in autonomous programs that allow a program director to establish individual points of distinctiveness that vary from program to program (Henry, 2009). NATA- 
accredited PPATEPs do undergo ongoing program evaluation by the PostProfessional Graduate Review Committee. PPATEPs are required to submit annual reports and are up for reaccreditation every 5 years (Commission on Accreditation of Athletic Training Education, 2008).

\section{Lack of PPATEP Research}

Although there has been a recent push for assessment and improvement of quality education in athletic training, much of that focus has been directed towards undergraduate ATEPs. Research focusing on undergraduate curriculum proposes ideas on how to alter or introduce new types of learning into current standards (Heinerichs, 2010). Research focusing on students of undergraduate ATEPs has ranged from recruiting athletic training students and clinical proficiencies, to student retention (Weidner, 2006). Program directors of undergraduate ATEPs are also a common topic, with research focusing on burnout, perceptions on job selection, and problems concerning administration (Judd, 2004; Perkins, 2001; Walter, 2009).

Research regarding PPATEPs is still in its infancy, with most articles dating from 2004 to present (Reed, 2004). Of this limited research, most approach athletic training education from the perspective of the athletic training student. Issues such as curricular satisfaction, stress and coping responses, and prediction of academic achievement have been identified, analyzed and addressed (Henry, 2009; Keskula, 1995; Reed, 2004). The most noteworthy and insightful article pertaining to graduate athletic training education to date is Neibert's (2009) qualitative interview 
of graduate students. Neibert's interviews revealed graduate students' perceptions of the principles of their programs in a theme he titled "from novice to expert." This article extols the benefits of continuing education in athletic training (Neibert, 2009).

There is currently no qualitative research on program directors of NATAAccredited PPATEPs. Pitney (2002) outlined qualitative research as it pertains to athletic training, stressing its use regarding educational and professional development issues. Relatively unused in the field of athletic training, qualitative research, and the various approaches it embodies, can be utilized to investigate the increasingly complex athletic training environment (Pitney, 2002). The flexible nature of PPATEPs would best be understood through qualitative research and indepth discussion focusing on program directors (Pitney, 2002).

\section{Purpose of the Study}

The purpose of this study was to conduct a qualitative analysis on postprofessional athletic training education program directors' perceptions of quality in post-professional athletic training education.

\section{Limitations}

The study may have been limited in the following areas:

1. The participants' ability to accurately reflect their experiences and feelings in the context of specific questions.

2. The study does not reflect the perceptions of program directors that are currently applying for initial accreditation by the NATA. 


\section{Delimitations}

The study was delimited to:

1. A sample size of 15 program directors from NATA-accredited post-professional athletic training education programs.

2. The use of program directors of NATA-accredited post-professional athletic training education programs only.

\section{Definition of Terms}

1. Evidence-Based Medicine. Evidence-based medicine is defined as the integration of the best research evidence with clinical expertise and patient values to make clinical decisions (Steves, 2004, p. 83).

2. Burnout. Burnout is defined as a negative response to stress displaying emotional exhaustion, depersonalization, and a lack of personal accomplishment (Walter, 2009, p. 190).

3. Reflection. Reflection in student journal takes three forms. Content reflection is the process of thinking about the actual experience. Process reflection is thinking about how to handle the experience. Premise reflection involves examining the socially constructed assumptions, beliefs and values regarding the experience (Kuiper, 2009, p. 78).

4. Mentorship. Mentorship is defined as a component of the professionalsocialization process that can help an individual develop values, skills, knowledge, and attitudes throughout their academic and professional careers (Pitney, 2009, p. 344). 


\section{Summary}

A lack of research on PPATEPs has contributed to the non-proliferation of NATA-accredited graduate programs. While undergraduate athletic training and nursing programs have increased in quantity and quality, largely due to selfreflective research, graduate athletic training programs have not enjoyed the same progress. Through analysis of undergraduate athletic training education research, cross-referenced by research in nursing education, comprehensive perception of quality by program directors has been identified as an unexplored area of significance in PPATEP research. It is important for the growth and success of accredited PPATEPs that self-reflective research now focuses on the people shaping and managing these programs. A qualitative inquiry into program directors' perceptions of the NATA's 2002 Standards and Guidelines for Post-Certification Graduate Athletic Training Education Programs yielded significant insight into the current structure and outline of post-professional athletic training education. 


\section{Chapter 2}

\section{Review of Literature}

The purpose of this review of literature is to provide a foundation and justification for performing a qualitative study of post-professional athletic training education program directors. Research topics pertaining to both entry-level undergraduate athletic training education programs and nursing education programs will be highlighted. Ideas such as different educational models (Kapborg, 2002) and teaching and leadership strategies have been introduced through literature and then incorporated into nursing education programs (Pierson, 2010). This self-examination is a means to improve upon areas of strength and reform areas of failure (Candela, 2008. A review of research conducted on postprofessional athletic training education highlights the points of distinction and areas of neglect. Finally, an assessment of qualitative research and interviewing in the field of athletic training emphasizes its benefits and necessity in the field.

\section{Nursing}

Nursing is an entry-level allied healthcare profession that shares many similarities with athletic training, both in organization and educational structure (Henry, 2009). With several governing bodies and many journals that publish research on the profession and its education system, nursing is a much older and larger profession than athletic training. Nursing education programs are similar to athletic training education in that both classroom education and clinical internship are pillars of the educational structure (Kapborg, 2002). Due to its large body of 
research, role as a prominent healthcare profession, and similarities to athletic training, nursing serves as an appropriate cross-reference when examining the body of athletic training research.

\section{Evidence-Based Medicine}

Evidence-based medicine (EBM) as the "integration of the best research evidence with clinical expertise and patient values to make clinical decisions" (Steves, 2004, p. 83). It is believed that EBM is necessary because it provides clinicians with tools for finding and analyzing evidence so that athletic trainers can benefit from the work of other clinicians described in medical literature. In the same article, Steves (2004) identified the steps to practicing EBM as follows: 1. Defining Clinically Relevant Questions, 2. Searching for the Best Evidence, 3. Critically Appraising the Evidence, 4. Applying the Evidence, 5. Evaluating the Performance of EBM. The key component to performing these steps successfully is critical thinking. Critical thinking is required of athletic trainers who practice EBM because it requires thoughtfully and systematically seeking conclusions to unanswered questions, as well as using clinical research to re-evaluate methods that most athletic trainers believe are tried and true (Steves, 2004).

While Steves (2004) believed that EBM focused on the clinical aspect of athletic training, several articles advocate placing an emphasis on EBM in the classroom. Educational models that incorporate research learning into undergraduate and graduate courses are necessary to create clinical athletic trainers that are invested and engaged in medical research literature (Martin, 2009). 
The emergence of NATA-accredited graduate programs is also said to have a positive effect on the production of quality research by placing post-professional athletic trainers alongside tenured athletic training faculty, thus increasing the number of original research publications produced (Myer, 2009). Evidence-based medicine has also experienced a recent surge in significance in the field of nursing. A 2010 article talked about the benefits of the "clinical ladder program" and its foundation in EBM (Pierson, 2010). Still in its infancy, EBM in nursing is currently being defined and implemented into clinical nursing rotations (Scott, 2008). These articles also place an emphasis on critical literature review and putting researchbased practice into action (Pierson, 2010; Scott, 2008).

\section{Mentorship}

Research on mentorship between students and clinical instructors has been performed qualitatively in both athletic training and nursing (Cahill, 1996; Pitney, 2009,). In athletic training, Pitney (2009) describes mentorship as a component of the professional-socialization process that can help an individual develop values, skills, knowledge, and attitudes throughout their academic and professional careers. The study used grounded theory to qualitatively interview 13 athletic training students and 3 individuals identified as mentors. Pitney found that while mentors must make themselves accessible and approachable, students must take initiative for a strong mentoring relationship to develop.

Cahill (1996) had previously used a qualitative approach to gain insight into the subjective experiences of third-year nursing students' and their thoughts on 
mentorship. The participants identified approachability as quality of a good mentor. They also stated that mentor relationships strengthened as they progressed through the program, becoming constructive and valuable during the transition out of the program into full-time nursing. Cahill concluded that a major theme during the interview was the notion of control versus support. Rather than supporting nursing students, many mentors used their experience and knowledge to maintain and control the professional hierarchy of nursing (Cahill, 1996).

\section{Problems and Challenges}

Research on athletic training education is a valuable tool used for assessment, addressing problems and challenges as seen by the athletic training community (Turocy, 2002). Until 1988, the Journal of Athletic Training was the only means of printed communication between athletic trainers and athletic training education faculty. Ideas on curriculum and problems facing athletic training education were assessed through research published in the JAT (Knight, 1999).

Problems and concerns facing athletic training students are a common thread of athletic training research. Weidner et al. (2006) studied the scope of clinical education for athletic training students working in the collegiate/university setting. They found that athletic training students are often unsupervised at their clinical site and that they often perform duties outside their scope of clinical education (Weidner, 2006). In their 2006 article the role of clinical education is more clearly defined, as is the role of clinical proficiencies and clinical instructors. Evaluation of clinical proficiencies was looked at more closely in 2008 as a response 
to Weidner's article (Walker, 2008; Weidner, 2006). Areas of clinical proficiency included orthopedic and clinical examination and assessment, therapeutic modalities, conditioning and rehabilitative exercise, and risk management. Standardized clinical proficiencies did not match well with the variability of clinical experiences and that simulation must be incorporated in order to practice all required proficiencies (Walker, 2008).

Program directors of entry-level undergraduate ATEPs are frequently in the spotlight of athletic training research. Their role as both clinician and instructor puts importance and stress on their position (Perkins, 2001). Program directors must balance time between students, program administration, scholarship, service, and possibly patient care (Walter, 2009). This ever-evolving role creates unique problems that have been continually addressed through research (Judd, 2004). Perkins and Judd (2001) noted that the profile of program directors was evolving as well, with fewer clinical responsibilities and educationally with more doctoral degrees. They also noted that this decrease in clinical responsibilities and lack of contact with student athletes was an emerging dilemma, and source of frustration, program directors were facing. Walter et al. (2009) noted the same emerging dilemmas facing program directors and cited this as a source or contributor to burnout in undergraduate program directors. The study took into account variables such as tenure status, gender, age, years experience with ATEPs, and years at current job. A significantly higher amount of female program directors were found to experience burnout than male program directors (Walter, 2009). 
Regarding the increase of tenure-track doctoral-educated program directors, Perkins et al. (2001) found that an increasing number of program directors were expected to make presentations and publish articles in peer-reviewed journals, often with annual requirements of minimum articles published. This supports the conclusion of Myer et al (2009) that this increase in highly educated faculty can and has begun to result in an increase in research pertaining to athletic training education. Athletic training research will continue to help educators and clinicians identify areas within athletic training education that require further validation (Turocy, 2002).

One of the most pressing issues facing nursing and nursing education is the shortage of RN's in the workplace and nursing students in the classroom (Magnussen, 2003). Janiszewski et al (2003) identified several factors that are contributing to the shortage and their impact on nursing education. They stated that an aging RN workforce and difficulty attracting nurses to teaching positions resulted in limited student enrollment and a decrease in the number of nursing school graduates. An increase in career opportunities outside nursing was also found to be a contributing factor to the decline of enrollment in nursing programs. In 2010, Rich et al stated that while the percentage of RN's entering the workforce is increasing, the rate at which it is increasing is not enough to meet rising demand. In order to meet rising patient load and demand of RN services, current nursing programs would need to graduate $90 \%$ more nurses (Rich, 2010). A shortage of nursing educators was identified as the primary factor. Nursing schools are 
restricted in the number of students that can be admitted to a program when there are insufficient numbers of doctoral-prepared faculty. Rich supported Yordy's (2006) outline of factors attributing to nursing faculty shortage:

1. A lack of interest in faculty careers in favor of growing opportunities within and outside of health care.

2. An emphasis on pre-requisite, long clinical careers before entering academia.

3. Fluctuations in nursing school enrollment during the last 30 years.

4. Academic salaries that are not competitive with salaries earned for clinical practice and administration.

5. The high cost of obtaining the education needed to enter academia.

6. Dissatisfaction with a teaching career due to high workloads, low salaries, and institutional pressures.

7. Inadequate funding from institutions to hire additional faculty (Yordy, 2006).

Many of these factors are comparable to the dilemmas of program directors of both entry-level undergraduate ATEPs and PPATEPs (Perkins, 2001). Rich et al (2010) found that many of these factors are being targeted in an attempt to lure more nurses into faculty positions. Reducing the financial gap between clinical and academic practice and the costs of advanced education are needed to attract and retain new nurse educators. Some state legislatures are finding funds to increase 
nursing faculty salaries and provide educators' dependents with tuition waivers (Yordy, 2006).

\section{Research on Post-Professional Athletic Training Education}

Some of the first research done on graduate athletic training programs dealt with prediction of academic achievement (Keskula, 1995). In 1995 there were 13 NATA-approved PPATEPs. Continuing education was quickly becoming popular in the profession and number of applicants into programs greatly outnumbered seats available. The study by Keskula et al (1995) examined predictor variables used in the applicant selection process, including Graduate Record Examination (GRE) scores, grade point average, total hours clinical experience, and the student's undergraduate athletic training. GPA was found to be the best predictor of academic success, whereas GRE scores and clinical hours did not contribute significantly to prediction. The study did not take into account success in clinical experiences (Keskula, 1995).

Reed et al (2004) evaluated stress and coping responses of certified graduate assistant athletic training students. Although the study was not limited to graduate assistants of NATA-accredited PPATEPs, the scope of the study is applicable. The authors interviewed three male and three female graduate assistant athletic training students, with the focus being on sources of stress and coping responses. Reed et al. identified athletic training duties, comparing job duties, responsibilities as a student, time management, social evaluation, and future concerns as sources of stress. Coping responses included planning, instrumental social support, adjusting to job 
responsibilities, positive evaluations, emotional social support, humor, wishful thinking, religion, mental or behavioral disengagement, and activities outside the profession. Reed et al (2004) concluded that graduate assistant athletic training students should be encouraged to use problem-focused and emotion-focused forms of coping with stress.

Henry et al. (2009) assessed curricular satisfaction levels of NATA-accredited PPATEP graduates. The survey examined overall satisfaction of graduates as related to the 2002 Standards and Guidelines for Development and Implementation of NATAAccredited Post-Professional Graduate Athletic Training Education Programs. The 10 proposed areas of satisfaction included depth of learning, breadth of learning, instructor availability, critical thinking, theoretic basis, writing skills, scholarly growth, community return, leadership, and overall satisfaction. Henry et al. hypothesized that 2005 and 2006 graduates would be more than $80 \%$ satisfied in each aspect. None of the ten categories had mean levels of $80 \%$ or higher, with critical thinking, overall curricular satisfaction, and depth of learning as the three highest categories. The autonomy and variability between programs was cited as a limitation in assessing satisfaction across different programs. It was stated that future research should take into consideration an individual program's points of distinctiveness (Henry, 2009).

The perspective of program directors with regard to graduate athletic training education has only been previously assessed through quantitative research. Seegmiller (2006) surveyed 353 athletic training educators including 12 of the 14 
PPATEP directors on their perception of quality in PPATEPs. Although the article assesses graduate athletic training education, athletic training educators from undergraduate programs were included as subjects. Athletic training educators from both non-accredited ATEPs and non-accredited PPATEPs were also included in the survey. Seegmiller found that educators found agreement for most quality indicators. An interesting finding was that educators with doctoral degrees ranked research as a more important quality than did educators with master's degrees. Seegmiller's final statement summarizes that "athletic training educators must take responsibility for the quality of their programs through continuous self-assessment" (p. 420).

Neibert (2009) used grounded theory to discover the theoretic constructs that confirm, disconfirm, or extend the principles of graduate athletic training education, and their applications appropriate for NATA-Accredited PPATEPs . Thirteen graduates from NATA-accredited PPATEPs were interviewed regarding these principles. A pilot study was conducted with two of the participants to determine appropriateness of the interview questions. The author stated that, "if we are to continue to achieve the principles of accredited post-professional athletic training education, we must strive to expand this theoretic position and search more deeply within the theoretic constructs of this position" (Neibert, 2009, p. 389). It was concluded that the participants confirmed and extended the principles proposed by the Standards and Guidelines for Development and Implementation of NATA-Accredited Post-Professional Graduate Athletic Training Education Programs 
and that these principles serve to progress the clinician's practice from novice to expert (Neibert, 2009).

\section{Summary}

An examination of athletic training research illustrates that while research in PPATEPs is growing, it is pales in comparison to the fields of undergraduate ATEPs and nursing education. Current research on PPATEP' is following the same path as both undergraduate ATEPs and nursing as established models and guides to follow. Qualitative research has been previously utilized in both nursing and athletic training education to assess questions not accurately assessed quantitatively. An area of interest only previously analyzed quantitatively, program directors' perceptions of quality have not yet been analyzed using qualitative methods. 


\section{Chapter 3}

\section{Methodology}

This study was a qualitative investigation, designed to elucidate program directors' perceptions of quality in NATA-accredited PPATEPs. An overview of the participant selection, interview structure and procedures, and qualitative data analysis is contained in this chapter.

\section{Qualitative Reasoning}

The use of qualitative research in this study was intended to obtain insight into the structure of post-professional athletic training education, the process by which PPATEPs are established and maintained, and the problems that program directors face in doing so. This approach has been used to assess the perceptions of graduates from PPATEPs and has yielded insight into the purpose of continuing education of athletic trainers (Neibert, 2009).

\section{Participants}

Participants were 6 NATA-accredited post-professional athletic training education program directors. This accounts for $40 \%$ of the total population. Participants were contacted via email, and contact information was solicited through the NATA on the education page of the NATA website at http://www.nata.org/education/educational-programs. Participants were selected based on availability. All participants have been through the NATA accreditation process, and all participants possessed a doctoral degree. 


\section{Instrumentation}

A semi-standardized interview protocol with the six principles outlined in the Standards and Guidelines for Development and Implementation of NATAAccredited Post-Professional Graduate Athletic Training Education Programs as the base for essential questions was utilized. An interview guide with the six essential questions and structured neutral probing questions will help direct the course of the interview (Berg, 2004). A pilot interview was performed prior to interviewing participants. All phone interviews were conducted on the researcher's home office landline. Audio was recorded for transcription using the Universal Host ${ }^{\mathrm{TM}}$ Desktop Digital Hybrid by JK Audio. Audio was transcribed verbatim using Microsoft Word from Microsoft Office 2008.

While telephone interviews lack the face-to-face nonverbal cues that quality researcher may use to direct the interview, they still provide effective means for interviewing participants (Berg, 2004). In instances where geographical location of subjects makes interviews nearly impossible, telephone interviews are an extremely effective method. Telephone interviews took place during normal working hours and the researcher called to set up the interview one to two weeks prior to the official interview.

The researcher maintained a researcher's reflexive journal throughout the study. The reflexive journal was analyzed to verify consistency and logical decision making throughout the study. It provided a detailed account of all decisions and documentations made regarding the study (Pitney, 2002). 


\section{Procedures}

All requirements established by the San José State University Human Subjects Institutional Review Board were met. Prior to the interview, signed consent was obtained from each participant. All participants emailed or faxed the provided consent to participate in research form prior to interviewing. All participants chose a pseudonym to provide anonymity.

Interviews were conducted over the phone at the convenience of each individual participant. Interviews were conducted in depth and audio recorded. Interviews ranged from $45 \mathrm{~min}$ to $90 \mathrm{~min}$ in length. The participants were not given any background information regarding the questions prior to the interview. Interviews followed the outline of the interview protocol. Participants were then asked to provide their thoughts on each given principle. Probing questions were utilized as needed, when the researcher believed that more data were required on a given subject (Berg, 2004). The initial grand tour question required participants to summarize their thoughts on the Standards and Guidelines for Development and Implementation of NATA-Accredited Post-Professional Graduate Athletic Training Education Programs as it pertained to their program. Participants were also allowed to ask questions at the end of the interview. All interviews adhered to the same format, and follow-up interviews were scheduled as needed (Berg, 2004).

\section{Analysis of Data}

Participant interviews were transcribed and analyzed using coding to group data into higher order themes moving from general to specific (Berg, 2004). Open 
coding is the process of data collection when the researcher identifies units of textual data that have significance based on the study's purpose. Axial coding is the process of forming categories and subcategories in order to create explanations about the phenomena. Selective coding involves organizing the categories of data around a central theme. The central theme is the category that can best explain the phenomenon and all other categories relate to it. Through coding, concepts are organized to best fulfill the stated purpose of the study (Pitney, 2002).

Establishing trustworthiness is fundamental to the quality of the study. Trustworthiness refers to the reader's perception of the quality of the study, based on the techniques used and manner in which the findings of the study were established. Thomas et al (2005) identified four principles as being essential to the quality of qualitative research, specifically credibility, transferability, dependability, and confirmability. These concepts help ensure the competency and value of the study.

Credibility is similar to the concept of internal validity. Thomas et. al (2005) identified peer debriefing, triangulation, and member checking as three methods of establishing credibility. Peer debriefing is conducted by recruiting other researchers who examine the data and the conclusions, questioning the researcher and his presentation of the findings (Thomas, 2005). The thesis advisor served as a peer debriefer in this study. All debriefers met frequently until all parties were satisfied with the credibility of the study. Triangulation refers to the use of multiple independent sources of data to support a conclusion (Thomas, 2005). The 
conclusions drawn from this study were examined and cross-referenced with Seegmiller's (2006) study on the perceptions of quality for graduate athletic training education, Henry et al's (2009) study on curricular satisfaction levels of graduates from NATA-accredited PPATEPs, and finally, Neibert's (2009) qualitative study on the idea of novice to expert practice via post-professional athletic training education in order to establish triangulation and credibility. These sources served to provide data on graduate athletic training education from multiple points of view in a variety of research methodologies.

Transferability is a concept that pertains to the ability of a study, or the design of a study, to relate or be useful in other similar settings (Thomas, 2005). It is similar to the external validity of a study. A study's transferability is in the hands of the reader but the researcher can state which settings may be relatable. The conclusions of the data of this study transfer to non-accredited PPATEPs that attempt to structure themselves according to the Standards and Guidelines for Development and Implementation of NATA-Accredited Post-Professional Graduate Athletic Training Education Programs. The structure of this study is transferable to any education program where program directors have standardized principles on which to structure their program.

Dependability relates to the quality of the data gathered in a study (Thomas, 2005). The researcher needs to be flexible and react critically to unpredictable answers given during an interview session. Dependability in this study was established by conducting a pilot interview. The researcher and a member of the 
thesis committee critically assessed this interview for design and data collection methods making adjustments to the interview guide and interviewing technique where needed.

Confirmability refers to the inherent bias of a researcher when conducting a study. Dependability and confirmability together serve to ensure the reliability of a study. The researcher must clarify his or her biases and how they will attempt to manage or minimize them. The researcher of this study acknowledges that he is a student of a NATA-accredited PPATEP and is interested in pursuing a doctoral degree in education, with the hopes of becoming a program director of an athletic training education program. The researcher's personal experiences in the field of athletic training and within the PPATEP may be considered a bias in his perspective of athletic training education. An inquiry audit will allow the researcher to demonstrate integrity and congruity with data collection. A researcher's reflexive journal of all documentation will allow an auditor to perform an extensive inquiry audit.

\section{Summary}

The qualitative nature of this study will provide great detail and insight into the perspective of program directors and the values and principles of postprofessional athletic training education. The delimitations of the study also provide for a clear perspective from NATA-accredited PPATEP directors, whereas previous research included educational faculty from a variety of backgrounds. 
Trustworthiness was ensured and quality was bolstered through the use of the researcher's reflexive journal and the utilization of peer debriefing and triangulation. 


\section{Chapter 4}

\section{Results and Discussion}

While the participants came from a variety of backgrounds, interests, geographic regions, and institutions, their responses to the interview guide provided a high degree of homogeneity. Analysis of the data revealed three major themes: a) Participants' relationship with the accreditation process and Standards and Guidelines, b) The role and benefits of attending an accredited PPATEP, and c) The future or sustainability of accredited PPATEPs.

These themes are supported by various subthemes that serve to highlight specific facets within a given theme. The theme of the participants' relationship with the accreditation process was supported by the subthemes of the accreditation site visit, a program's points of distinction, and a program director's personal philosophy regarding the Standards and Guidelines. The theme of the benefits of attending a PPATEP was supported by the subthemes of leadership, research proficiency and comprehension, critical thinking, and clinical refinement. The theme of sustainability of PPATEPs was supported by the subthemes of departmental support, the role of the entry-level masters program, support from undergraduate ATEPs, and the non-proliferation of PPATEPs. These subthemes not only support and further explain the main themes, but also expand on ideas identified in previous research. 


\section{Program Directors Relationship With Standards and Guidelines}

The NATA's Standards and Guidelines were established to outline the requirements for establishing and maintaining accreditation of PPATEPs. Participants described their relationship with the Standards and Guidelines and the accreditation process in great detail. Participants generally viewed the loose structure of the accreditation guidelines as allowing for more autonomy, compared to the relatively rigorous accreditation guidelines faced by undergraduate ATEPs. This notion was also viewed with some hesitation. As Peter noted, "It's hard to go from something as rigid as the CAATE's document and then come over to this document and say, ok, this concept is accounted for by, like, three of these things, when you know, it's left wide open to interpretation..." Participants viewed the site visits and construction of points of distinction as helping to shape and polish their personal philosophy regarding graduate-level education.

Points of distinction. Participants viewed points of distinction as the main vehicle for establishing autonomy. This autonomy fostered a program's ability to strengthen and tailor their specific curriculum as they see fit. Henry et al (2009) found that curriculum satisfaction was one of the highest-rated aspects of graduate education by students. Identified factors influencing points of distinction included geographical factors, such as climate or ethnic/cultural background of student population, school limitations or specializations, and supporting faculty's interests and backgrounds. 
We've paid particular interest to the points of distinction because we didn't really have those in place very well. So we spent a lot of time formulating our three points of distinction and we spent a lot of time on creating objectives and outcomes underneath each of those three points of distinction. We've created a new curriculum that meets both those points of distinction as well as the specialties of the faculty that is here. That's another thing that the guidelines suggest, that you have points of distinction and you know, play to the specialties of the faculty and we've done both now. So our current curriculum is a lot stronger than it was a couple years ago, because we are now meeting both of those guidelines. (Michelle)

Michelle's comment best summarizes the relationship between site visit, points of distinction, and curriculum. Lisa viewed the same theme from the viewpoint of applying students, stating "I can actually turn to a student and say I hear you saying you want this kind of program so you should look into this school over here, because it's structured completely different than ours and seems to match your goals better." (Lisa)

Site visit. Participants commonly viewed site visits by the accreditation committee as learning experiences that helped identify perceived weaknesses in a program's structure or content. Michelle recommended thick skin and openmindedness:

Being open minded to the fact that the accrediting committee is going to need to make changes. And to be open minded that there is going to be a need for that. I think sometime when you get set in your ways that it's nice to feel that way and then when the accrediting body is like "Oh You know, here are new standards, you need to make a couple changes," you have to be open minded and willing to do that. (Michelle) 
While probation and loss of accreditation are possible outcomes of a site visit, participants stated that recommendations on how to better emphasize points of distinction are more common. These potential outcomes during site visits prompted one participant to remark “... I could recognize areas where the NATA would prefer we did even more and so I could look to look at places in our program where we could emphasize certain things and build them up." (Lisa) Peter expressed apprehension towards openly divulging perceived weaknesses during a site visit, concluding:

To let you behind the curtain, on the first day they say, "ok, well what do you need?" Well that's an open-ended question that sounds like a trap, right? Ok, so you want me to identify the shortcomings and put them on the table right away and that way you can get on the next plane out of here, so it's learning to politic with the NATA, learning to politic with the PPERC, um, getting your ducks in a row in terms of your clinical affiliations, they need to be on board with what you're doing. (Peter)

Personal philosophy. While participants had varying personal philosophies regarding the Standards and Guidelines, most stated that their personal opinions pertaining to athletic training education came first and that viewpoint was then filtered through the document. Peter stated "let's try and really meld this to our philosophy, let's build the standards around the philosophy, not build the philosophy around the standards, because the philosophy has to be there, let's face it, you don't get hired unless the philosophy is there..." (Peter) Lisa also held the same view: 
I understand that there are standards and guidelines, but instead of sort of saying "here's how we need to change them to match these," I think it's more that we've been able to see our school through the eyes of the Standards and Guidelines, and then we can say, "here's how these things are matching the standards and here's these things match another standard or guideline. (Lisa)

This statement highlights the belief that personal philosophy must be established before attempting to comprehend the intentions of the Standards and Guidelines. Lisa also stated “Um, I don't know that the Standards and Guidelines can do anything to better my program, in my opinion. Again, I think those Standards and Guidelines aim to take the minimalist approach, so they're just telling you what the minimum is." (Lisa) Participants viewed this approach as allowing for autonomy, reiterated by Michelle, "I think it gives us enough structure where they feel solid about what we're doing here and meeting some standards, but I like the fact that nothing is too tight. They allow us to be unique." (Michelle)

\section{Benefits of Attending a PPATEP/Role of PPATEP}

Programs that achieve and maintain NATA-accreditation status go through a process that makes them stand apart from non-accredited PPATEPs. At times, that difference is not clearly defined. All participants spoke to the benefits of attending an accredited PPATEP. While their individual programs and points of distinction influenced their opinion on what exactly those benefits are, accredited PPATEPs were viewed as furthering an athletic trainer's education in ways that other graduate programs could not. Participants saw the role of their program as providing these benefits to their students, thereby enhancing their knowledge, 
clinical skills, employment power, and standing within the athletic training community. This finding further supports Neibert's (2009) central theme as taking one's practice from "novice to expert." One participant, Declan, reinforced the concept introduced by PPATEP graduates in Neibert's study, stating "It does need to be the next step in a person's professional development."

Leadership. Several participants brought up the concept of leadership as a focal point within accredited PPATEPs. When asked if they thought the Standards and Guidelines had omitted anything they thought paramount to their program, several participants mentioned leadership should be emphasized more. Leadership is mentioned twice within the Standards and Guidelines. It is identified as a goal of Post-Certification Athletic Training Education stating:

Instruction in advanced skills and knowledges, the preparation of certified athletic trainers for leadership roles, and a research experience are considered to be the distinguishing characteristics of graduate education in athletic training. Advanced educational experiences designed to enhance the certified athletic trainer's ability to function in clinical, teaching, administrative, or research environments are considered to be essential components of the postcertification graduate athletic training education program. While minimal graduate courses and resource requirements are specified in this document, flexibility and innovation in curricular development are encouraged.

While the Standards and Guidelines recognize leadership as a core tenet of postcertification athletic training education, they provide no specific examples of how or why leadership should be encouraged, keeping within the loose nature of the document, which most participants viewed as a positive thing. Peter thought that 
Standards and Guidelines should have a clearer message regarding the concept of leadership, stating “... but I think it's something that needs to be written in, I mean there's no doubt that their position on leadership is a little weak. I mean it's very vague, I could ask you know, "are you a leader?" to a hundred students, and they would all interpret that differently..." Some participants stated they attempt to foster leadership by making it a point of distinction, others through course requirements and curriculum direction. Peter made the connection between leadership and becoming politically involved with the NATA, asserting "...but you talk about building leaders in the field, and you can lead by example, but I think it's very important, and this is something the students brought to my attention, but I think we need to become involved in the politics of athletic training, and I think that is something that should be fostered at the grad level." (Peter)

Proficiency in research and research comprehension. Research proficiency and comprehension was commonly proposed as one of the main benefits of attending an accredited PPATEP. While commonly referred to in points of distinction, various aspects of research production and consumption were emphasized throughout course curriculum. Seegmiller's study previously indentified both program curriculum and research as factors that affect quality of programs and further expanded on research as having various facets to its implementation within a program (2006). Participants varied slightly in their views regarding research, but the two themes that emerged were producing better research in the field of athletic training and improving research analysis skills. 
These findings support and build upon the ideas introduced by Martin et al (2009) for engaging athletic training students in research educations in order to both appraise research and to potentially contribute to the knowledge of the profession. All participants stressed the importance of an original research assignment, usually a thesis or research project. One respondent, Michelle, stated it best:

All of our students are expected to do some type of original study. It doesn't matter if it's quantitative or qualitative or mixed or anything in between. We do ask that they do an original research study that involves a research question of some sort and then has data collection and analysis of results and interpretation of those. (Michelle)

Michelle explained that the concept of research production is introduced in their first semester and continually built upon throughout their education. Presentation at the regional and national levels, as well as publication in journals such as the Journal of Athletic Training, is advocated to all students. Several participants acknowledged that lengthy research projects may delay graduation, but that close mentorship from the beginning of their education can insure that a student attending an accredited PPATEP graduates on time. Myer et al (2009) previously stressed that mentorship regarding research in athletic training can have both negative and positive effects. A lack of mentorship opportunities can burden students, but overall the rise of research mentorship has the ability to foster the evolution of athletic training as a profession (Myer et al, 2009).

All participants referenced the importance of implementing the concept of evaluating research quality throughout their curriculum. Research comprehension and the implementation of evidence-based medicine were seen as primary 
objectives to instill in PPATEP students. Lisa described the relationship between

research production and research comprehension:

Um, and so they all have the opportunity to discover what it takes to do a good study and what kind of controls and limitations are there to doing good research, with the goal that when they read and article later, and of course they're doing it their whole masters degree, but ideally they'll keep doing it once they've left us, that they can say, you know, I don't buy it, these are the limitations that I think this paper never even talks about and I just don't put any credit into what they're saying, I'm not gonna change my behavior based on it, another time they may read a study and say, you know, I think they're right, I think they did it well... (Lisa)

Lisa illustrates that the process of producing quality research suitable for publication can help students better grasp what constitutes well-conducted research. Building upon this understanding, according to Lisa, students then learn to determine which research should affect their clinical decisions.

Critical thinking. The fostering of critical-thinking skills was often the first benefit participants mentioned. In-depth classroom discussion was most commonly identified as a means to cultivate critical thinking in students, as revealed by Michelle:

Most of the classes have an assignment where the student has a research article leader so they're in charge of a research article and they have to present it. And then they actually have to create critical thinking questions for the class where they have to lead them in discussion. We teach them how to create questions that will encourage their classmates to answer more thoughtfully, and then as a result they have to critically think what may come up with those types of questions. (Michelle)

In 2009, Neibert underscored theoretic understanding through critical thinking as an essential element to post-professional athletic training education as identified by 
students. This concept was reiterated by program directors during interviews. Peter best explained that mastery of a topic is "do you retain the information?" and critical thinking is "can you apply the information?" (Peter) This idea was referring to the concept of the Kinetic Chain Model, where Peter stated "I think that's a good example, because it becomes the building blocks for biomechanics, but it's up to the student to really interpret what's really going on." (Peter) Participants believed that accredited PPATEP serve to further a student's knowledge, as well as clinical skills.

Participants spoke to the importance of fostering critical thinking skills in the classroom and employing those skills at their clinical sites. This reflexive relationship between classroom and athletic training room was characterized as "going from bench to bedside." (Peter) Declan stated they encouraged translational education that goes from the classroom to the clinical setting and back. Lisa drew upon the same connection in her statement:

And now it trickles over into the clinical setting because they're answering those questions and problems everyday and what we're helping them with is, although we know it's a hard transition for everyone, is how do you take that critical thinking and thought in the classroom and when an athlete comes in and says, you know, "how long will I be out with this particular injury?" Then you have to go back to the science of what you know and figure it out... (Lisa)

Clinical refinement. The relationship between the classroom and the clinical aspect of athletic training was a major focus for most participants. Several participants claimed that extended education in the clinical aspect, under the guidance of an approved clinical instructor, or (ACI), was the single most important 
aspect of attending an accredited PPATEP. This perception contrasts the findings of Seegmiller, who found that doctoral-level educators stressed research as the singlemost important component factor affecting quality of program (2006). Lisa's comment disputes this idea.

Yeah, you know I said it before, we do really believe that the point of all this education is to make better clinicians ... constantly trying to tie in what you're doing in class, if it doesn't have any relation to the clinical aspect than it's useless, you're trying to become a better clinician, so how do you transfer that knowledge over into what you're doing and then our clinical mentors are really great at being involved in the program and understanding our goals, therefore they can help that to. (Lisa)

Lisa also highlighted that the goal reported by most students in her program is to become better-practicing athletic trainers. In order to reach that goal, students of PPATEPs need to be placed in quality clinical sites where they are working with mentors that have experience working with students.

You know, so in my mind, the most important component of putting together a quality masters program in athletic training is, you know, do you have quality opportunities for clinical education, so do you have places for people to work everyday, where they're not just going to be "ultrasound bunnies," but they are thinking, respected athletic trainers, where they're considered staff and they really can put their skills to work, but they have mentors to check in with and ask questions and stuff... (Lisa)

Declan best summarized the role a PPATEP plays with a student's clinical skills when he branded it as "clinical refinement."

What you have at the post-professional level is probably clinical refinement rather than true education... just because someone graduates from a professional program doesn't mean that they have 
mastery of all skills, their decision-making is still being refined. (Declan)

This concept of refinement captures what a lot of participants attempted to identify and further emphasized as the reflexive nature of graduate-level education. Students work on clinical decision-making skills in the field and reflect upon their decisions in the classroom with faculty and classmates to provide critical analysis. Participants' statements directly support the findings of Riley-Doucet and Wilson (1997), which introduced reflection into nursing programs through self-reflection, peer-group discussion, and self-awareness.

\section{Sustainability of PPATEPs}

The non-proliferation of accredited PPATEPs has called into question the sustainability of the current model of post-professional education. Participants spoke at length about the sustainability of the current model of accredited PPATEPs. Where opinions were somewhat homogeneous regarding the two previous themes, projections and outlooks on the sustainability graduate-level athletic training education varied. One source of uncertainty stemmed from the rise of entry-level masters athletic training education programs. Participants also placed varying amounts of concern or apprehension on internal support and support from undergraduate ATEPs.

Non-proliferation of programs. Participants identified the many causes for non-proliferation of accredited PPATEPs. Some causes, such as the rise of entry- 
level masters programs and a lack of support from undergraduate ATEPs, were touched on more deeply and warranted becoming a subtheme. Other perceived causes included a stable applicant pool. Lisa spoke to this root, stating "... if I was getting two hundred applicants for six spots, then I start telling my colleagues that, and those other schools can fill their GA positions because nobody really wants to go to a non-accredited program, then we'd see more accredited programs." (Lisa) Lisa also pointed to other reasons for the lack of newly accredited PPATEPs:

In order to get a masters, because I understand many jobs that are listed at the college level especially, they require you to have a masters, but they do not require you to have an accredited masters, so the number of people that have a masters degree is way higher than the number of accredited masters programs that exist, so if I'm a university and I have a masters program that allows athletic training students to get a GA position and get a degree in whatever I want them to get a degree in and they keep coming, then why would I bother getting accredited right? So I think there's a ton of masters programs out there that are probably worthy of accreditation or they would just need to make a couple of little tweaks here and there, but what's the incentive? As long as they're getting students in and out of their program, then why bother having the hoop, because that's a pretty big hoop to jump through, right? (Lisa)

Lisa's comment points to several factors for the non-proliferation of accredited PPATEPs. First, Lisa believes that the job market places little or no value on degrees specifically from accredited programs. This in turn deters many program directors from going through the accreditation process because they see it as not giving them any worth or significance for going through a tough, rigorous process. This finding is emphasized by Seegmiller's 2006 study that found that only $18 \%$ of non- 
accredited PPATEPs had plans to eventually seek accreditation, emphasizing the lack of incentive or desire to go through the accreditation process.

Role of entry-level masters. Participants viewed entry-Level Masters programs as a way to keep up with other health care professions, namely physical therapy. Participants also viewed entry-level masters programs as being a better way than undergraduate ATEPs to attract people that want to stay in the field of athletic training, rather than using it as a stepping-stone into another profession. Michelle best summed up this view, "We're gonna decrease numbers but get more people that want to be athletic trainers. That is one benefit of moving to this is that some of those choosing our entry level masters, that's because they really want to be AT's." (Michelle) Participants did propose that the rise of entry-level masters could potentially lead to the termination of accredited PPATEPs. Despite this, Lisa viewed the transition as a good thing:

But yeah, so, personally, even though our program would be obsolete if we went one hundred percent one way only, I would be the first person to vote for it... Yeah, because, I'm just optimistic, right? I mean, what, we will continue to, at our institution, we'll continue to do some kind of education, we'll just do it in a different light, right? We'll just do it in a different way, you know, I don't think that my own circumstance should have anything to do with what the right or wrong answer is, right? (Lisa)

Support from undergraduate programs. Participants unanimously stated that they felt support for accredited PPATEPs by undergraduate ATEPs was lacking. Reasons behind that lack of support were believed to included general unawareness of such programs, as described by Michelle, “I didn't go to a post professional 
program but I don't even think at that time, I was young and naïve if you asked me, I wouldn't have even realized that I wasn't." (Michelle) Participants also felt that undergraduate ATEP faculty and program directors openly discourage students from pursuing their master's degree from an accredited PPATEP.

Right now the big barrier that prevents a lot of undergraduate students from considering a post-professional program is the old mentality that graduate programs are just "more of the same," and that's a mindset that we need to need to get our undergraduate program directors out of. (Declan)

Declan's comment was reinforced by Lisa and Michelle, who believe that the nonproliferation of accredited PPATEPs is a direct result of a lack of support from undergraduate ATEP programs.

A lot of people are being guided the other way still, right? I know that there are still students, they'll even email me saying "I personally think it would be good to be accredited, but my mentors just keep saying I just need to get a masters in something else," so a lot of students are still being told don't go the route of an accredited athletic training masters program, so basically I don't think there's a demand for it. (Lisa)

I think a lot of other students don't realize it. They just, a lot of it comes from, why do we continue to have people in our own profession tell undergrads that they need to go get their masters in something else? It doesn't make any sense. (Michelle)

Departmental or internal support. Participants felt that accredited PPATEPs succeed or fail based on support from their department, school, and university. This reinforces Seegmiller's finding that adequate faculty, staff and administrative support was one of the main factors affecting program quality 
(2006). Programs benefitted from direct financial support and resources such as supporting faculty members. Michelle described the difficulty in initially finding support for a PPATEP:

But then it's about convincing the administration at your school, which is an obstacle that's beyond any other. Trying to convince the provost and the president. None of them want to have new program(s). The word "new program," is a scary word. That means money, and who has money right now? Nobody. So what if Maine wanted to build a program, that means they're going to have to go through all of that paperwork and ask the provost and president, and go to the board of trustees and then go to the Higher Education board, and you know, that's a large undertaking. (Lisa)

Declan also spoke to the importance of establishing support:

Um, the support is often based both under perceived importance of your program, it also, like it or not, there is a financial aspect in higher education and if you're a program that generates revenue, you're gonna get more support than those who generate less. (Declan)

Once support is established, the aspiration to become accredited must come from within the program, as well as the larger institution. Participants felt that their parent department or institution needed to understand the motivation behind becoming accredited in order to insure its success. Peter best articulated the need to foster understanding and ambition:

So again, I think support, weighing the cost-to-benefit, you know, if you don't know what accreditation is, why seek it? Again, I don't know why the department would support that, I guess they just want the piece of paper, but that's kind of putting the cart before the horse, you know, wait, why are we doing all this work for that and you don't fully understand what's driving this, right? (Peter) 
Jeff touched on the lack of being able to provide substantial financial support to his students, as being a limitation established by his university. While he maintains he has strong support regarding the accreditation process and faculty, limited financial support has narrowed his applicant search, stating "This has led us to a limited applicant pool that that is generally well-off financially and the lack of a tuition waiver is typically cited as the primary reason when applicants decline our offer of admission." (Jeff)

Most participants expressed the importance of supporting faculty being paramount to a successful accredited PPATEP. Lisa best explained the benefit of having a large faculty to support an accredited PPATEP:

Also, you know, I think you need a rich ability to bring in different people that would be interested in teaching courses that are directly relevant to the field of athletic training and will connect to someone's ability to become a master clinician. And again, you either have those resources around or you don't, so that's what I think are the biggest challenges, does your environment have the resources that you need to be successful or not. (Lisa)

George stated that being able to complete faculty hires "has enhanced student research and education experiences." (George) Michelle elaborated on this theme:

So our students have a wide variety of topics to choose from in terms of faculty research specialties, and we've had a couple times that a student picks a topic that's not within a faculty member's research specialty but usually it's within an area that we can still provide them guidance. So students get to do what they want while staying within our specialties so we can provide them the best mentorship possible. 
Peter spoke on the other side of this issue, to his lack of support from his parent institution, stating "So, I think they overloaded me in the end and my students saw a bit of deterioration and I just started to crack and I would equivocate it to burnout. (Peter). A lack of support not only limits the students experiences and opportunities, it puts stress on the program director. This supports previous findings that faculty, staff and administrative support directly influence curricular satisfaction levels of graduates from accredited PPATEPs (Henry, 2009; Seegmiller, 2004).

\section{Summary}

Three main themes surfaced while performing a qualitative analysis on program directors' perceptions of quality in NATA-accredited PPATEPs. These themes included the participants' relationship with the accreditation process and the NATA's Standards and Guidelines, the benefits of attending an accredited PPATEP, and the sustainability of accredited PPATEPs. While participant background created a variety of situations and perspectives, participants generally held the same opinions regarding the numerous aspects of their profession, their programs, and athletic training education. Participants felt that a program director needs to develop their own personal philosophy regarding graduate education and filter that philosophy through the Standards and Guidelines. This process includes establishing a program's points of distinction and making sure they are found and stressed throughout the curriculum as well as at students' clinical sites. Participants felt that when done correctly, there were distinct benefits of attending an accredited 
PPATEP, including leadership skills, research proficiency and comprehension, critical thinking, and clinical refinement. Finally, participants were somewhat unsure as to the future of post-professional education and the sustainability of the current model. 


\section{Chapter 5}

\section{Conclusions}

The purpose of this study was to gain insight into the perceptions of program directors from NATA-accredited PPATEPs. This included their thoughts on the accreditation process, the meaning behind accreditation, the benefits of attending an accredited PPATEP, the role of accredited PPATEPs in the field of athletic training, and the future or sustainability of accredited PPATEPs. While certified athletic trainers can pursue a master's degree in a variety of ways, these accredited PPATEPs undergo a process that has established a loose association with other similar programs from around the country. Although program directors of these accredited PPATEPs come from a variety of backgrounds and work in a variety of institutional settings, their belief in establishing and maintaining NATA accreditation has semi-standardized their opinions regarding post-professional athletic training education. This became apparent while performing interviews through the emergence of common themes between participants.

\section{Program Directors Relationship with Standards and Guidelines}

One of the primary themes that emerged was the participants' relationship with the accreditation process and the Standards and Guidelines. Participants spoke well of the document and stated that they thought a program director should have a clear voice and direction for their program before relying on the Standards and Guidelines to shape their program. Participants stated that some programs were established before accreditation was a possibility or option and that integrating a 
successful existing program into the regulations outlined in the Standards and Guidelines wasnot and shouldn't be difficult. The subthemes of the site visit, points of distinction, and personal philosophy regarding the Standards and Guidelines serve to highlight central aspects of a program director's relationship with the Standards and Guidelines.

Site visit. The participant perception of site visits by the accreditation committee was that they served to primarily ensure that a program director's personal philosophy and a program's points of distinction were being executed throughout the course curriculum and clinical experiences. Participants were very aware of the discrepancy in rigidity between undergraduate and graduate-level accreditation and expressed appreciation for room to develop distinct programs.

Philosophy regarding Standards and Guidelines. The unanimous feeling of the participants towards the document was that it was a minimalist attempt to outline the basic requirements for creating and maintaining an accredited PPATEP. They felt a program director should have his or her own personal philosophy regarding graduate-level education and then filter that philosophy through the Standards and Guidelines.

Points of distinction. Participants felt that by being allowed to create and foster their own points of distinction, program directors should play to the strengths of their faculty, institution, and even geographic region. Prospective students could then determine their preference for a given program based on that program's points of distinction. 


\section{Benefits of Attending a PPATEP/Role of PPATEP}

Another major theme was the role of graduate-level education in athletic training and the benefits of attending an accredited PPATEP. Participants felt that attending an accredited PPATEP was superior to receiving a master's degree in a field similar to athletic training. They stated that their athletic training-specific curriculum, combined with clinical experiences that reflect their program's philosophy, provided for a higher-quality education than non-athletic trainingspecific programs or degrees. Participants' perceptions of the benefits of attending an accredited PPATEP were strongly reflected in the principles of graduate education, outlined in the Standards and Guidelines and subject to focus in Neibert's 2009 article. Participants felt specifically that principles such as leadership, research proficiency and comprehension, critical thinking, and clinical refinement stood out as benefits of attending their programs.

Leadership. Participants felt that their students should embrace the role of leadership due to their extended education within the field of athletic training. While participants embraced the loose nature of the Standards and Guidelines, the document's position on leadership and explicitly how to foster it was one of the few areas they said could benefit from more clearly defined direction. Participants chose to view this emphasis on leadership in a variety of ways, including administratively, politically, or clinically. These personal beliefs were then implemented throughout their curriculum or points of distinction. 
Research proficiency and comprehension. Participants focused on their emphasis on comprehension and proficiency when discussing research in athletic training and the concept of evidence-based medicine. All participants felt that research was a strong benefit of attending an accredited PPATEP, although they chose to focus on it in a variety of ways. Some participants felt that graduate-level education should focus on producing quality research in order to advance the field. Many programs strongly recommend or require all students to produce a thesis and or submit their work for publication. Other participants felt that research production was not a goal of all students and that research comprehension and implementation into practice should be focused on. All participants spoke to both aspects, but chose to emphasize one versus the other due to their own interests, philosophies, faculties, and institutions.

Critical thinking skills. All participants stressed the promotion of criticalthinking skills. They stated that this is mainly done by in depth classroom discussion and translational education that stresses the relationship between classroom and clinical site. This concept was expressed by one participant as "going from bench to bedside." (Peter) Participants stressed that undergraduate education should teach breadth, whereas graduate-level education should stress depth. This philosophy aligns with the concept of points of distinction, where a program can identify several specific areas to focus on with great intensity. Carefully evaluating and critically examining aspects of these points of distinction in class allows for a more conscious application of the knowledge in the clinical realm. 
Clinical refinement. "Clinical refinement" was a phrase coined by Declan, a participant, to explain the benefit of extended clinical education. Participants felt that a student attending an accredited PPATEP as a certified athletic trainer could be alternatively working in the field without the supervision or mentorship of an approved clinical instructor. These ATC's working in the field have the base clinical skills from their undergraduate program, but are missing the opportunity to refine those skills under the guidance of a more-experienced ATC that believes in the program's ideals and points of distinction. Several participants believed that the ultimate goal of their program was to produce better clinicians and that quality clinical sites were as important as curriculum direction and content. Their students' mastery of clinical skills and their decision-making process are improved upon in a way that cannot be replicated in other types of programs.

\section{Sustainability of PPATEPs}

The future of graduate-level athletic training education produced the most wide-ranging results from participants. There were many noted factors that affected not just the success of their own program, but the future accredited masters programs. Several of these factors warranted becoming subthemes under the sustainability of PPATEPs. These subthemes included nonproliferation of accredited PPATEPs, departmental support, support from undergraduate ATEPs, and the role of entry-level masters programs.

Nonproliferation of PPATEPs. Participants reported many possible causes for nonproliferation of PPATEPs. Opinions varied on factors affecting success of 
existing programs and growth of new programs, including several that developed into their own subthemes discussed later. Several participants pointed to a stable applicant pool as a factor. While participants were satisfied with the quality of their applicants, they reported that the number of applicants they see has not increased. Also, participants felt that employers do not view PPATEP graduates as having an advantage over other job applicants. While a master's degree is required or highly recommended for many positions, a degree from an accredited PPATEP is not seen as having higher value. These two situations create an atmosphere in which seeking accreditation, a reportedly arduous task, is seen as a lot of work with little reward. Participants felt that a change in either situation would result in more programs seeking accreditation.

Department/internal support. Support from a program's department, school, or university was often cited as one of the most influential factors in the success of an accredited PPATEP. Participants acknowledged that the financial aspect of running a program might often be a limiting factor in the growth or achievement of a given program. Initially impressing the administration or emphasizing the perceived importance of a program is a necessity. Once established, another important factor is emphasizing the importance of seeking and maintaining accreditation. Participants that felt their programs did not fully understand the importance of seeking accreditation felt it much more difficult to seek and maintain.

Participants stated that support from their departments included release time, assisting faculty, and financial support for students. Release time allowed 
PPATEP administration to work on self-studies, visit clinical sites, and meet with students. Participants with larger faculty reported feeling more supported. They also were able to expand on their programs interests, student research directions, and educational experiences by bringing in faculty from a variety of backgrounds. Financial support for students, usually grants or tuition waivers, allow program directors to attract students from different financial backgrounds. Participants that lacked financial support for students cited that it was often reported as the reason an applicant chose another program. Limitations in any of these three arenas changed participants' reported success with their programs.

Support from undergrad programs. The success of accredited PPATEPs is directly related to support from undergraduate ATEPs. PPATEPs must compete with a variety of programs in related fields for students coming out of undergraduate ATEPs. A significant portion of those students does go into other fields, but many remain in athletic training and pursue a master's degree from programs other than accredited PPATEPS. Participants that previously reported a steady annual applicant pool believe that support from undergraduate ATEPs is lacking. They attributed some lack of support to generally not being informed to the existence, let alone the merits, of accredited PPATEPs. Several participants reported not being aware of accredited PPATEPs when they were an undergraduate student themselves. Other participants felt that undergraduate program directors believed that accredited PPATEPs offered "more of the same," when it came to educational content. (Declan) 
Role of entry-level masters programs. Participants viewed entry-level masters programs in athletic training as beneficial for the future of the profession. While participants acknowledged they could signal the eventual end to the current undergraduate and post-professional programs, they are a way to stay competitive with other health care professions. This transformation could result in less people entering the field of athletic training, but yield a higher retention rate. Participants saw this as a positive thing and did not view their jobs as hindering them from supporting a different educational structure.

\section{Recommendations for Further Study}

Recommendations for further study include probing further into the accreditation process from a program director's perspective. This includes further questioning on site visits, such as preparing, expectations, conclusions drawn, and perception of the accreditation committee and site visit process. Participants seemed the most apprehensive to talk about this process compared to other aspects of their profession and their candid opinion on the process would be valuable.

Further questioning about specific relationships between graduate and undergraduate program directors, whether at their same institution or regionally, would provide insight as to the relationship between faculty and administrators of both types of programs. Participants spoke unanimously about the lack of support from undergraduate programs. In depth, specific examples and additional insight into why graduate program directors perceive that lack of support would further support this research. 


\section{Areas for Future Research}

Future research should include the perspectives of those known and named by program directors as influencing the success or failure of a program. This includes approved clinical instructors, assisting faculty, and administrators of accredited PPATEPs. Their perceptions on the significance of accreditation and the role of program directors would be beneficial on determining the importance of accreditation for PPATEPs.

The perceptions of employers on the benefits of graduating from an accredited PPATEP while applying for positions would also be an interesting area of future research. While people from within accredited programs tout their strengths and benefits, an outsider's opinion would give insight into some of the practical benefits of graduation from an accredited PPATEP. Other outsiders such as program directors that have chosen not to pursue accreditation and students who have entered non-accredited PPATEPs would also provide for a more balanced view as to the role of accreditation for graduate level athletic training education.

\section{Implications}

Several implications may be drawn from this research. From the interviews it was clear that there was not a lot of communication between some participants. While the level to which the program directors interacted was not directly established, it seemed their autonomy led to some distance between colleagues. Most participants were not sure as to the number of accredited programs currently in existence. Hopefully participating in this research, describing their experiences in 
detail, reflecting upon their field and specific position within it, and learning that research was being conducted on their programs will lead them to establish a better connection with one another.

It is clear from this research that participants were adamant about the concrete benefits of attending an accredited PPATEP. Their recognition and description of these benefits and strengths attempted to identify their programs as standing apart from programs of similar backgrounds. In the opinion of the participants, attending an accredited PPATEP after becoming a certified athletic trainer is the best course to further one's education and clinical skills. While further research should serve to investigate this claim, this should belief should be emphasizing the widespread acceptance and success accredited PPATEPs.

The widespread proliferation of accredited PPATEPs has not been seen and participants had several opinions why. These proposed reasons for the nonproliferation of their programs have been identified and improving these identified areas should be addressed. Relationships between PPATEP program directors and both administration and undergraduate program directors need to be strengthened and various educational committees of the NATA should play a supporting role.

Participants expressed the most uncertainty regarding the future of postprofessional education. This portion of the interviews was usually full of speculation and ambiguity as to what would happen regarding accredited PPATEPs and entry-level masters programs. This study should emphasize this apparent 
uncertainty and cause the NATA to better clarify their intentions regarding the future of education within the field.

\section{Summary}

The purpose of this study was to qualitatively examine program directors' perceptions of quality in NATA-accredited PPATEPs. Program directors from accredited PPATEPs are in a unique position and undergo a detailed process to attain and uphold NATA accreditation, whereas many similar programs do not. Their input on the challenges they face, the ideals they advocate, and the benefits they promote have previously gone unaddressed in athletic training research. Through the conduction of phone interviews their views were established and analyzed. Although these participants come from a wide array of backgrounds their opinions held a high degree of uniformity. Their positivity and enthusiasm for their profession and positions was very evident and they offered many areas where they thought improvement was possible. They felt that their programs offered knowledge and experience that was unparallel, but that they needed support from several directions in order to thrive. Participants spoke to the future of athletic training education with uncertainty towards the structure, but with confidence in the content and professional in the field. 


\section{References}

American Nurses Association (2007). Historical review. Retrieved from http://www.nursingworld.org/FunctionalMenuCategories/AboutANA.aspx

Berg, B.L. (2004). A dramaturgical look at interviewing. In B.L. Berg, Qualitative research methods for the social sciences (pp. 75-119). Boston, MA: Pearson Education.

Cahill, H. A. (1996). A qualitative analysis of student nurses' experiences of mentorship, Journal of Advanced Nursing, 24, 791-799.

Candela, L., Bowles, C. (2008). Recent RN graduate perceptions of educational preparation, Nursing Education Perspectives, 29, 266-271.

Commission on Accreditation of Athletic Training Education (2008). Overview of the commission. Retrieved from http://caate.net/dynamic/about_us_menu.html

Delforge, G.D., Behnke, R.S. (1999). The history and evolution of athletic training education in the United States, Journal of Athletic Training, 34(1), 53-61.

Fong, C.M. (1990). Role overload, social support, and burnout among nursing educators, Journal of Nurse Educators, 29(3), 102-108.

Heinerichs, S., Gardiner-Shires, A.M. (2010). Incorporating service learning in athletic training. Athletic Training Today, January, 36-38.

Henry, K.J., Van Lunen, B.L., Udermann, B., Onate, J.A. (2009). Curricular satisfaction levels of national athletic trainers' association - accredited postprofessional athletic training graduates. Journal of Athletic Training, 44, 391-399. 
Janiszewski-Goodin, H. (2003). The nursing shortage in the United States of America: an integrative review of the literature, Journal of Advanced Nursing, 43, 335-350.

Judd, M.R., Perkins, S.A. (2004). Athletic training education program directors' perceptions on job selection, satisfaction, and attrition, Journal of Athletic Training, 39, 185-192.

Kaiser, D.A. (2004). Reflective journals in athletic training clinical education, Athletic Therapy Today, 9, 39-41.

Kania, M.L., Meyer, B.B., Ebersole, K.T. (2009). Personal and environmental characteristics predicting burnout among certified athletic trainers at national collegiate athletic association institutions, Journal of Athletic Training, 44, 58-66.

Kapborg, I, Fischbein, S. (2002). Using a model to evaluate nursing education and professional practice, Nursing and Health Sciences, 4, 25-31.

Keskula, D.R., Sammarone, P.G., and Perrin, D.H. (1995). Prediction of academic achievement in an NATA-approved graduate athletic training education program, Journal of Athletic Training, 30, 55-56.

Knight, K.L., Thompson, C. (1999). 44 years of “The Journal”, Journal of Athletic Training, 34, 397-406.

Kuiper, R., Pesut, D., Kautz, D. (2009). Promoting the self-regulation of clinical reasoning skills in nursing students, The Open Nursing Journal, 3, 76-85. 
Magnussen, L., Amundson, M.J. (2003). Undergraduate nursing student experience, Nursing and Health Sciences, 5, 261-267.

Martin, M., Myer, G.D., Kreiswirth, E.M., Kahanov, L. (2009). Research engagement: a model for athletic training education, Athletic Therapy Today, 14, 27-30.

Myer, G.D., Kreiswirth, E.M., Kahanov, L., Martin, M. (2009). Longitudinal Evaluation of Journal of Athletic Training author credentials: implications for future research engagement in athletic training, Journal of Athletic Training, 44, 427433.

National Athletic Trainers' Association (n.d.) Accredited-Programs. Retrieved from http://www.nata.org/education/educational-programs/accreditedprograms

National Athletic Trainers' Association. (n.d.). History of NATA. Retrieved from http://www.nata.org/about_NATA/history.htm

National Athletic Trainers' Association (Jan 2002). Standards and guidelines for post-certification graduate athletic training education programs. Retrieved from http://www.nata.org/student/strdsguide.pdf

Neibert, P.J. (2009). Novice to expert proactive via postprofessional athletic training education: a grounded theory, Journal of Athletic Training, 44, 378-390.

Perkins, S.A., Judd, M.R. (2001). Dilemmas of program directors: then and now, Journal of Athletic Training, 36, 396-400. 
Pierson, M.A., Liggett, C., and Moore, K.S. (2010). Twenty years of experience with a clinical ladder: a tool for professional growth, evidence-based practice, recruitment, and retention. Journal of Continuing Education in Nursing, 41, 33-40.

Pitney, W.A., Parker, J. (2002). Qualitative research applications in athletic training, Journal of Athletic Training, 37, 168-173.

Pitney, W.A., Ehlers, G.G. (2004). A grounded theory study of the mentoring process involved with undergraduate athletic training students. Journal of Athletic Training, 39, 344-351.

Pryjmachuk, S., Richards, D.A. (2007). Predicting stress in pre-registration nursing students, British Psychological Society, 12, 125-144.

Reed, S., and Giacobbi Jr., P.R. (2004). The stress and coping responses of certified graduate athletic training students. Journal of Athletic Training, 39, 193-200.

Rich, K.L., Nugent, K.E. (2010). A United States perspective on the challenges in nursing education, Nurse Education Today, 30, 228-232.

Riley-Doucet, C., Wilson, S. (1997). A three-step method of self-reflection using reflective journal writing, Journal of Advanced Nursing, 25, 964-968.

Scott, K., McSherry, R. (2008). Evidence-based nursing: clarifying the concepts for nurses in practice, Journal of Clinical Nursing, 18, 1085-1095.

Seegmiller, J.G. (2006). Perceptions of quality for graduate athletic training education, Journal of Athletic Training, 41, 415-421. 
Steves, R. Hootman, J.M. (2004). Evidence-based medicine: what is it and how does it apply to athletic training? Journal of Athletic Training, 39, 83-87.

Thomas, J.R., Nelson, J.K., Silverman, S.J. (2005). Research Methods in Physical Activity. Champaign, IL: Human Kinetics.

Turocy, P.S. (2002). Overview of athletic training education research publications, Journal of Athletic Training, 37, 162-167.

Walker, S.E., Weidner, T.G., Armstrong, K.J. (2008). Evaluation of athletic training students' clinical proficiencies, Journal of Athletic Training, 43, 386-395.

Walter, J.M., Van Lunen, B.L., Walker, S.E., Ismaeli, Z.C., Oñate, J.A. (2009). An assessment of burnout in undergraduate athletic training education program directors, Journal of Athletic Training, 44, 190-196.

Weidner, T.G., Henning, J.M. (2002). Historical perspective of athletic training clinical education, Journal of Athletic Training, 37, 222-228.

Weidner, T.G., Henning, J.M. (2002). Being an effective athletic training clinical instructor, Athletic Therapy Today, 7, 6-11.

Weidner, T.G., Noble, G.L. Pipkin, J., B. (2006). Athletic training students in the college/university setting and the scope of clinical education. Journal of Athletic Training, 41, 422-426.

Yordy, K.D. (2006). The nursing faculty shortage: a crisis for health care. Princeton, NJ: The Robert Wood Johnson Foundation to the Association of Academic Health Centers. 


\section{Appendix A: Interview Guide}

Intro questions:

1. a) How did you initially become involved in athletic training?

b) How did you become involved in the education aspect of athletic training?

2. What is your level of understanding regarding the NATA's Standards and Guidelines for Post-Certification Graduate Athletic Training Education Programs?

3. How are the Standards and Guidelines for Post-Certification Graduate Athletic Training Education Programs integrated into your PPATEP?

4. Questions regarding the specific principles:

a) How is the concept "Mastery of Subject Matter" incorporated into your PPATEP?

b) How is the concept "Critical Thinking" incorporated into your PPATEP?

c) How is the concept "Theoretical understanding" incorporated into your PPATEP?

d) How is the concept "Proficiency in research or creative activities" incorporated into your PPATEP?

e) How is the concept "Service Orientation" incorporated into your PPATEP?

f) How is the concept "Diverse representation of perspectives" incorporated into your PPATEP?

5. Do you feel there are principles that are vital to your program which are not outlined within the Standards and Guidelines? 
6. Do you feel that the Standards and Guidelines for Post-Certification Graduate Athletic Training Education Programs provide a valid structure for a PPATEP?

7. Do you have any suggestions on how the Standards and Guidelines could better fit the needs of your PPATEP? 


\section{Consent Form}

\section{Appendix B: Consent Form}

\section{Agreement to Participate in Research}

Responsible Investigator(s): Joshua Pendleton, graduate student at San Jose State University

Title of Study: Program Directors' Perceptions of Quality in NATA-Accredited Post-Professional Athletic Training Education Programs

1. You have been asked to participate in a research study investigating program directors' perceptions of the NATA's 2002 Standards and Guidelines for Post-certification Graduate Athletic Training Education Programs.

2. You will be asked to discuss at length your perceptions of the structure of the NATA's standards and guidelines, as well as discuss the current state and future of graduate athletic training education.

3. Emotional discomfort is a potential risk while participating in this study. Emotional discomfort may occur while talking about the problems or hurdles of establishing and maintaining an accredited post-professional athletic training education program (PPATEP).

4. This study will help to shed light on the nature of PPATEPs and the struggles that program directors face while running them. This self-reflection will benefit the NATA, program directors, educators wishing to establish an accredited PPATEP, and students wishing to attend an accredited PPATEP.

5. Although the results of this study may be published, no information that could identify you will be included. Pseudonyms will be used for all participants to guarantee anonymity.

6. There is no compensation for participating in this study

7. Questions about this research may be addressed to:

Joshua Pendleton

(714) 335-3433

ipendleton83@gmail.com

Complaints about the research may be presented to:

Shirley Reekie, Ph.D., Department Chair, Kinesiology

(408) 924-3012

Shirley.Reekie@sjsu.edu

Questions about a research subjects' rights, or research-related injury may be presented to Pamela Stacks, Ph.D., Associate Vice President, Graduate Studies and Research (408) 924-2427.

8. No service of any kind, to which you are otherwise entitled, will be lost or jeopardized if you 
choose not to participate in this study.

\section{CONTINUED ON NEXT PAGE}

9. Your consent is being given voluntarily. You may refuse to participate in the entire study or in any part of the study. You have the right to not answer questions you do not wish to answer. If you decide to participate in the study, you are free to withdraw at any time without any negative effect on your relations with San Jose State University.

10. At the time that you sign this consent form, you will receive a copy of it for your records, signed and dated by the investigator.

- The signature of a subject on this document indicates agreement to participate in the study.

- The signature of a researcher on this document indicates agreement to include the above named subject in the research and attestation that the subject has been fully informed of his or her rights.

Participant's Signature

Date

Investigator's Signature

Date 